\title{
Sensitivity of Tomatoes at Mature-green and Breaker Ripeness Stages to Internal Bruising
}

\author{
Steven A. Sargent', Jeffrey K. Brecht ${ }^{2}$, and Judith J. Zoellner ${ }^{3}$ \\ Vegetable Crops Department, Institute of Food and Agricultural Sciences, University of Florida, \\ 1255 Fifield Hall, Gainesville, FL 32611
}

Additional index words. Lycopersicon esculentum, grading, sorting, quality control, mechanical damage, mechanical injury, handling, cultivars

\begin{abstract}
Internal bruising (IB) caused by handling impacts results in disruption of normal ripening in tomato (Lycopersicon esculentum Mill.) locular gel. It was selected as an injury indicator to investigate the effect of drop height $(0,10,20,30 \mathrm{~cm})$ onto an unpadded surface and number of impacts (one or two) for three tomato cultivars. For mature-green (MG) tomatoes, significant incidence of IB (5\% to 45\%) was found in all cultivars for single drops on opposite sides of fruits from $20 \mathrm{~cm}$; two drops on the same location from $20 \mathrm{~cm}$ caused $20 \%$ to $30 \%$ IB. Breakerstage (BR) tomatoes were more sensitive to impacts than MG. Single drops from $10 \mathrm{~cm}$ on opposite sides of BR fruits caused $15 \%$ to $73 \% \mathrm{IB}$, depending on cultivar. Two drops on a single location from $10 \mathrm{~cm}$ caused $50 \%$ to $68 \%$ IB. 'Sunny' was less susceptible to IB than 'Solar Set' or 'Cobia' (formerly NVH-4459).
\end{abstract}

Mechanical injury is the leading cause of qualify loss at wholesale and retail levels for apples, head lettuce, peaches, potatoes, and strawberries (Wright and Billeter, 1975). Although parasitic disease was the primary cause of loss for Florida and California tomatoes at retail and consumer levels, the predominant decay organisms present were those that can infect produce only at sites of mechanical injury (Ceponis and Butterfield, 1979). Tomatoes grown in Florida and other production areas commonly are shipped over long distances under conditions that can promote the growth of decay organisms at sites of mechanical injury (e.g., impact and pressure bruises, cuts, punctures, and abrasions). Therefore, since mechanical injury is cumulative, the various handling steps from field to consumer must be carefully coordinated and integrated to minimize losses in product quality.

Halsey (1955) determined that most externally damaged tomatoes were removed during sorting and grading. However, tomatoes harvested after BR of maturity (showing $1 \%$ to $10 \%$ red; U.S. Dept. Agr., 1976) were more sensitive to IB than those harvested MG. IB is not readily apparent until the tomato is nearly red. IB was described by Halsey (1955) for red-ripe tomatoes as a "watersoaked cellular breakdown of the crosswall and locular areas," predominantly at the locules. Tomatoes sampled at the turning stage (10\% to $30 \%$ red) after packing and ripening showed $37.7 \%$ IB. Hatton and Reeder (1963) described IB in red-ripe tomatoes as a breakdown of the locular gel from the normal, clear pink to a cloudy, yellowish, "stringy, gelatinous tissue"; in severe cases of IB, the locular tissue became dry and placental tissue became watersoaked. However, they found only $2.9 \%$ IB for MG tomatoes sampled after packing and ripening.

We have previously reported the incidence of mechanical injuries (bruises, cuts/punctures, abrasion, and IB) for four tomato

\footnotetext{
Received for publication 19 Oct. 1990. Journal Series no. R-01120 of the Florida Agricultural Experiment Station. The mention of specific tradenames and companies is for informational purposes only and does not constitute endorsement by The Univ. of Florida nor The Institute of Food and Agricultural Sciences, to the exclusion of others. The cost of publishing this paper was defrayed in part by the payment of page charges. Under postal regulations. this paper therefore must be hereby marked advertisement solely to indicate this fact.

'Assistant Professor.

${ }^{2}$ Associate Professor.

${ }^{3}$ Biological Scientist.
}

cultivars sampled at several points during handling from field through packing (Sargent et al., 1989a, 1989b). IB was determined to be cumulative during handling. Tomatoes handled at BR were significantly more susceptible to IB than those handled MG. For 'Sunny', BR tomatoes sampled from bins in the field had $36 \%$ IB and those sampled after packing in the packinghouse had 63\% IB. MG fruits sampled at these same locations had $10 \%$ and $24 \%$ IB, respectively. Similar results were obtained for 'Solar Set', 'Cobia', and BHN-39 tomatoes. Thus, it appears that incidence of IB is sensitive to accumulated impacts occurring during normal harvesting and handling operations.

IB can be induced using controlled drop tests of fruit onto a rigid surface. With increasing number of impacts to individual tomatoes dropped from $40 \mathrm{~cm}$ in the laboratory, MacLeod et al. (1976) found accelerated $\mathrm{CO}_{2}$ and $\mathrm{C}_{2} \mathrm{H}_{4}$ production and increased incidence and severity of IB.

External bruises are caused by failure of the outer pericarp due to cell rupture or fracture between cells when the tissue receives an impact above the bio-yield point (Holt and Schoorl, 1982; Mohsenin, 1970). However, IB can be caused by impacts lower than the bio-yield point if the impact energy is transmitted to the underlying locular tissue with sufficient force so as to impair ripening, as indicated by subsequent abnormal color development and increased gel viscosity. Whether the effect of the impact on ripening is direct or indirect has not been established.

Consumer purchases of tomatoes at two supermarkets showed that red-ripe tomatoes were preferred to pink tomatoes (Hicks et al., 1975). There is a growing trend by many supermarket chains to include "vine-ripe" tomatoes in the produce section as a premium-priced selection. As commonly used in the tomato industry, the term "vine-ripe" refers to tomatoes that are harvested after BR, i.e., when at least $10 \%$ of the fruit surface shows a definite color change from green to tannish yellow, pink, or red (U.S. Dept. Agr., 1976). Although IB is normally not detectable in the packinghouse, it is detectable at the consumer level and its unsightly presence may affect repeat sales.

The purpose of this study was to investigate the effect of drop height, ripeness stage, and number of impacts per site on incidence and severity of IB. Since IB is the most sensitive form of mechanical injury that is readily detectable, it was selected

$\overline{\text { Abbreviations: }} \mathrm{BR}$, breaker-stage; IB, internal bruising; MG, mature-green. 
as an injury indicator for tomatoes, even though it is not associated with decay under normal handling situations.

\section{Materials and Methods}

Three cultivars (Sunny and Solar Set, Asgrow Seed Co., Kalamazoo, Mich., and Cobia, formerly' known as NVH-4459, Northrup King Co., Gilroy, Calif.) were hand-harvested in commercial fields in the Ruskin/Bradenton, Fla., production area. These cultivars were selected for the study because 'Sunny' was the most widely grown cultivar in Florida during the 1988-89 season, accounting for $>70 \%$ of the tomato hectarage, and 'Solar Set' was the second-ranked cultivar with 7\%. 'Cobia', a relatively new release, was planted on $<1 \%$ of the hectarage (Maynard, 1990).

'Solar Set' and 'Cobia' were harvested at the MG stage on 11 and 25 May 1989, respectively, since there were insufficient amounts of BR tomatoes available in the fields. 'Sunny' was harvested on 9 June 1989 at MG and BR stages. Tomatoes of medium size (63 to $72 \mathrm{~mm}$ in diameter; Florida Tomato Committee, 1989), were harvested directly into polystyrene cell-pack trays (Niles Packaging, Niles, Mich.) to avoid injury, returned to the laboratory at Gainesville the same day, and kept overnight at 20C. The day following harvest, half of the 'Solar Set' and 'Cobia' tomatoes were placed in ripening chambers at $23 \mathrm{C}$ and

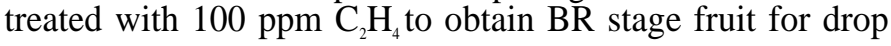
tests.

The day following harvest, MG fruits from each cultivar and BR fruits from 'Sunny' were individually dropped from either 10,20 , or $30 \mathrm{~cm}$ onto a solid aluminum block surface. Ethylenetreated 'Solar Set' and .'Cobia' fruits were dropped 5 days later upon reaching BR. For each drop height/ripeness stage $(\mathrm{n}=$ 40), 20 fruits were individually dropped once each on opposite sides at the equator, and 20 fruits were dropped twice on the same location at the equator. Each tomato was held by vacuum at the desired height to avoid rotation during the drop and to permit repetitive drops on the same site according to the procedure of Sober et al. (1989). Each fruit was caught after the first bounce, the impact area was marked, and the fruit was stored at $23 \mathrm{C}$ for later evaluation. Preliminary drop tests (S.A.S., unpublished data) revealed insignificant amounts of external bruises for MG and BR tomatoes dropped from 10 to $30 \mathrm{~cm}$; therefore, only IB was rated in this test. The previous tests also indicated that a single drop from $30 \mathrm{~cm}$ was sufficient to induce IB.

Upon reaching the firm, red-ripe stage, tomatoes were evaluated for incidence and severity of IB by slicing each tomato through the equator. All locules with seeds were individually rated for IB using the following scale (locules without seeds were not rated or included in the totals, since these tended to be small and misshapen): $0=$ none, gel red, clear, liquid; 1 = slight, minimal gel discoloration (light tan color) at locule margin (between seeds and inner pericarp wall); 2 = moderate, noticeable gel discoloration (greenish-tan color) at margin; gel in contact with locular wall; $3=$ severe, desiccation of gel (yellow-green color, viscous), separation of gel from locular wall. The incidence of IB was determined on an individual-fruit basis for each treatment, calculated from the number of tomatoes that had at least one locule exhibiting moderate or severe IB divided by the total number of tomatoes for the treatment $(n=20)$. Only fruits exhibiting moderate and severe IB were included in the total fruit with IB, since it was decided that consumers would have deemed tomatoes with these ratings objectionable. The severity distribution of IB was determined on a locule basis since some fruits had several locules with IB, ranging from slight to severe. Thus, for each treatment, the number of locules for each severity rating (slight, moderate, or severe IB) was divided by the total number of locules containing seeds for the 20 tomatoes in the treatment. Statistical analyses were performed on a randomized complete block experimental design using analysis of variance for a linear response (SAS Institute, Inc., 1985).

\section{Results}

In general, both incidence and severity of IB increased with increasing drop height; BR tomatoes were more susceptible to IB than MG, and two drops at the same location caused more IB than a single drop (Tables 1-3). 'Sunny' was less susceptible to IB than the other cultivars. For MG 'Sunny' tomatoes, a single drop on opposite sides from $20 \mathrm{~cm}$ was sufficient to induce IB in $20 \%$ of the fruits (Table 1A). Of all locules with seeds in this treatment, $<4 \%$ were rated either slight or moderate for incidence of IB, and $<1 \%$ were rated severe. Dropping MG 'Sunny' fruit from $30 \mathrm{~cm}$ increased incidence of IB to $31.6 \%$ of the fruits and almost doubled the amount of moderately injured locules. MG 'Sunny' tomatoes were virtually undamaged when dropped on opposite sides from $10 \mathrm{~cm}$, while $15 \%$ of BR 'Sunny' had IB when dropped from this height (Table 1A); for BR fruits that were injured, most of the IB locular injury was slight. BR tomatoes dropped from 20 and 30 $\mathrm{cm}$ had 4- and 5-fold increases in IB, respectively, and significantly higher severity ratings.

Two drops of MG 'Sunny' tomatoes on the same side from $20 \mathrm{~cm}$ caused a 50\% increase in the incidence of IB (Table 1B) compared with one drop each on opposite sides from $20 \mathrm{~cm}$ (Table 1A); the severity ratings for injured locules from single or double drops, however, were similar. BR 'Sunny' tomatoes dropped twice on the same side also were substantially more injured than fruits dropped once, and at a lower height than for MG fruits dropped under similar conditions. Dropping BR fruits twice from 10 or $20 \mathrm{~cm}$ increased the incidence of IB 3.3-fold and 1.3-fold, respectively (Table IB), relative to BR fruits dropped once on opposite sides (Table 1A).

For MG 'Solar Set' tomatoes, one drop each on opposite sides from 10 and $20 \mathrm{~cm}$ caused IB in 5\% of the fruits in each case (Table 2A). However, when dropped from $30 \mathrm{~cm}$, nine times as many MG fruits were injured and with substantially higher percentages of moderately and severely injured locules. Incidence of IB for MG fruits dropped twice on one side from 20 $\mathrm{cm}$ increased four times to $20 \%$ (Table $2 \mathrm{~B}$ ) over those dropped once each on opposite sides from $20 \mathrm{~cm}$ (Table 2A). BR 'Solar Set' tomatoes were very susceptible to IB. Nearly $75 \%$ of the BR fruits dropped once on opposite sides from $10 \mathrm{~cm}$ had IB, and all fruits had IB when dropped once from 20 and $30 \mathrm{~cm}$ (Table 2A). As drop height increased from 10 to $20 \mathrm{~cm}$, the percentage locules rated moderate IB doubled to $>20 \%$; locules rated severe IB increased $>3$-fold to $>24 \%$ as drop height increased from 20 to $30 \mathrm{~cm}$. Two drops per side resulted in similar incidence and severity of IB for BR 'Solar Set' fruits (Table 2B).

MG 'Cobia' tomatoes dropped once on opposite sides from $20 \mathrm{~cm}$ were more than twice as susceptible to IB (Table $3 \mathrm{~A}$ ) as MG 'Sunny' dropped from the same height (Table 1A), and were nine times as susceptible as MG 'Solar Set' (Table 2A). However, MG 'Cobia' fruits dropped twice on the same side (Table 3B) and BR 'Cobia' fruits dropped once or twice per side (Table 3 A, B) had similar incidence of IB compared with 
Table 1. Effect of ripeness stage and drop height on incidence of IB of 'Sunny' tomatoes.

\begin{tabular}{|c|c|c|c|c|c|}
\hline \multirow[b]{3}{*}{ Variable } & \multirow[b]{3}{*}{$\mathrm{N}$} & \multicolumn{4}{|c|}{ Internal bruising } \\
\hline & & \multicolumn{2}{|c|}{$\mathrm{F} r$ u i t inc } & \multicolumn{2}{|c|}{$\begin{array}{l}\text { Locules with } \\
\text { cated severity }(\%)^{y}\end{array}$} \\
\hline & & cted ( & ight & Moderate & Severe \\
\hline \multicolumn{6}{|c|}{ A. One drop each on opposite sides } \\
\hline \multicolumn{6}{|c|}{ Ripeness stage } \\
\hline MG & 80 & 12.7 & 1.9 & 2.7 & 0.4 \\
\hline $\mathrm{BR}$ & 80 & 40.0 & 1.3 & 5.6 & 5.4 \\
\hline & & $* *$ & NS & ** & $* *$ \\
\hline \multicolumn{6}{|c|}{ Drop ht $(\mathrm{cm})$} \\
\hline 0 & 40 & 0.0 & 0.0 & 0.0 & 0.0 \\
\hline 10 & 40 & 7.5 & 2.9 & 1.4 & 0.0 \\
\hline 20 & 40 & 40.0 & 1.7 & 6.2 & 2.8 \\
\hline \multirow[t]{2}{*}{30} & 40 & 59.0 & 1.8 & 9.1 & 9.0 \\
\hline & 0 & $* *$ & NS & $* *$ & $* *$ \\
\hline \multicolumn{6}{|c|}{ Interactions } \\
\hline \multicolumn{6}{|c|}{$\underset{\mathrm{MG}}{\text { Stage }} \times$ drop ht } \\
\hline 0 & 20 & 0.0 & 0.0 & 0.0 & 0.0 \\
\hline 10 & 20 & 0.0 & 0.6 & 0.0 & 0.0 \\
\hline 20 & 20 & 20.0 & 3.4 & 3.8 & 0.7 \\
\hline 30 & 20 & 31.6 & 3.7 & 7.1 & 0.8 \\
\hline \multicolumn{6}{|l|}{ BR } \\
\hline 0 & 20 & 0.0 & 0.0 & 0.0 & 0.0 \\
\hline 10 & 20 & 15.0 & 5.1 & 2.8 & 0.0 \\
\hline 20 & 20 & 60.0 & 0.0 & 8.5 . & 4.9 \\
\hline \multirow[t]{2}{*}{30} & 20 & 85.0 & 0.0 & 11.0 & 16.8 \\
\hline & & $* *$ & $* *$ & NS & $* *$ \\
\hline
\end{tabular}

\begin{tabular}{cccccc}
\multicolumn{5}{c}{ B. Two drops on same side } \\
$\begin{array}{l}\text { Ripeness stage } \\
\text { MG }\end{array}$ & 60 & 10.0 & 2.1 & 1.3 & 0.6 \\
BR & 60 & $\begin{array}{c}43.3 \\
* *\end{array}$ & $\begin{array}{c}0.3 \\
* *\end{array}$ & 6.3 & 4.1 \\
& & & & $* *$ \\
Drop ht (cm) & & & & & \\
0 & 40 & 0.0 & 0.0 & 0.0 & 0.0 \\
10 & 40 & 25.0 & 1.2 & 3.3 & 0.6 \\
20 & 40 & 55.0 & 2.2 & 8.1 & 6.3 \\
& & $* *$ & $*$ & $* *$ & $* *$ \\
Interactions & & & & & \\
Stage $\times$ drop ht & & & & & \\
MG & & & & & \\
0 & 20 & 0.0 & 0.0 & 0.0 & 0.0 \\
10 & 20 & 0.0 & 1.7 & 0.0 & 0.0 \\
20 & 20 & 30.0 & 4.5 & 3.8 & 1.7 \\
BR & & & & & \\
0 & 20 & 0.0 & 0.0 & 0.0 & 0.0 \\
10 & 20 & 50.0 & 0.7 & 6.5 & 1.3 \\
20 & 20 & 80.0 & 0.0 & 12.4 & 10.9 \\
& & $* *$ & $*$ & $*$ & $* *$ \\
\hline
\end{tabular}

${ }^{2}$ Calculated from number of fruits with at least one locule showing moderate or severe IB.

${ }^{y}$ Calculated using the number of locules for each severity rating divided by the total number of locules with seeds for that treatment.

Ns, $* * *$ Nonsignificant or significant at $P=0.0 .5$ or 0.01 , respectively.

the respective treatments for 'Solar Set' (Table 2 A, B). MG and BR 'Cobia' had a higher percentage of locules rated severe than either 'Solar Set' or 'Sunny', regardless of number of drops or drop height (Tables 3, 2, 1, respectively).

\section{Discussion}

The incidence and severity of IB in tomatoes were affected by cultivar, drop height, number of impacts, and ripeness stage.
Table 2. Effect of ripeness stage and drop height on incidence of IB of 'Solar Set' tomatoes.

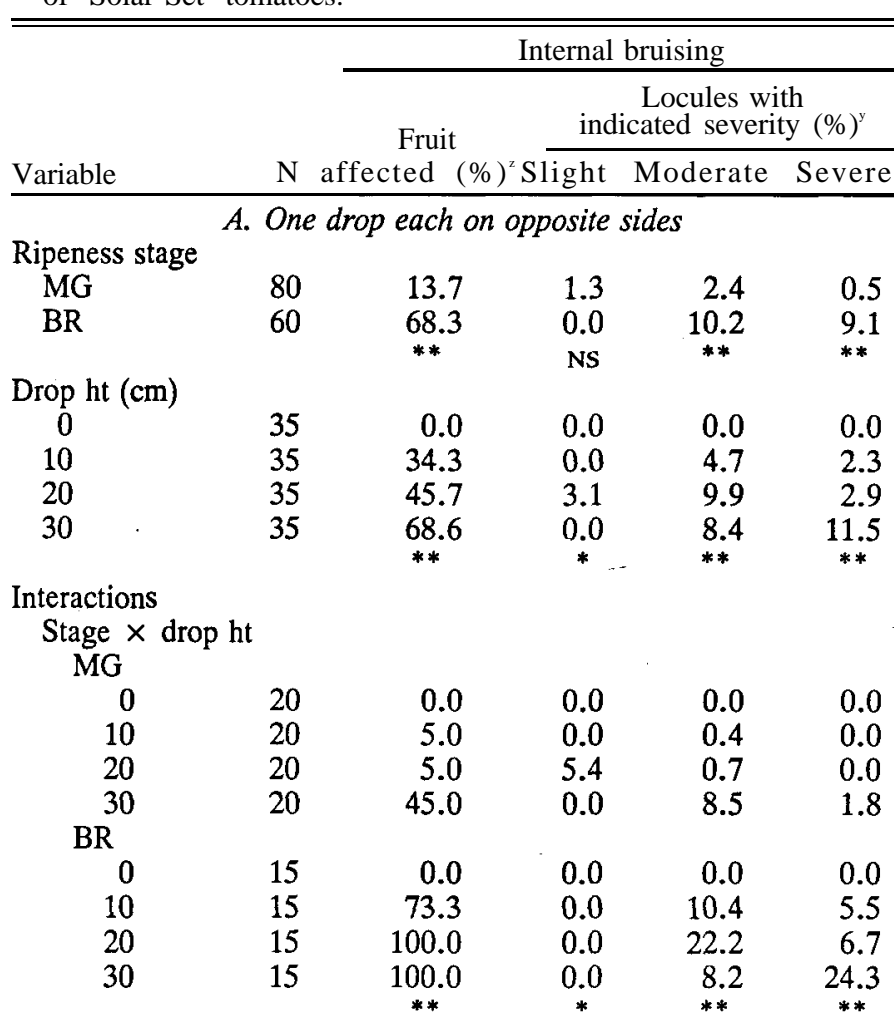

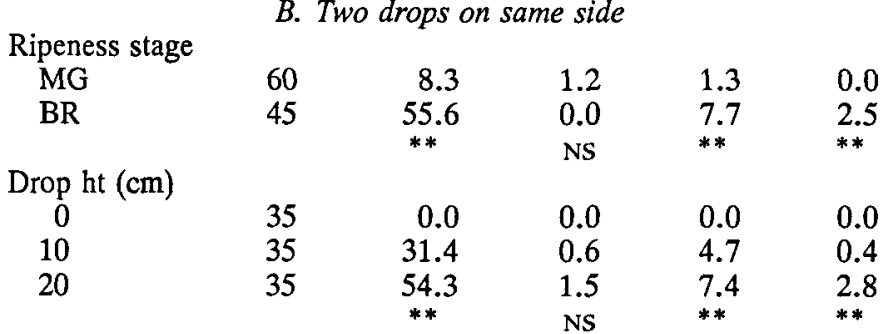

Interactions

Stage $\times$ drop ht MG

\begin{tabular}{|c|c|c|c|c|c|}
\hline 0 & 20 & 0.0 & 0.0 & 0.0 & 0.0 \\
\hline 10 & 20 & 5.0 & 1.0 & 0.7 & 0.0 \\
\hline 20 & 20 & 20.0 & 2.5 & 3.1 & 0.0 \\
\hline \multicolumn{6}{|l|}{ BR } \\
\hline 0 & 15 & 0.0 & 0.0 & 0.0 & 0.0 \\
\hline 10 & 15 & 66.7 & 0.0 & 9.9 & 1.0 \\
\hline \multirow[t]{2}{*}{20} & 15 & 100.0 & 0.0 & 13.2 & 6.5 \\
\hline & & $*$ & NS & $* *$ & $* *$ \\
\hline
\end{tabular}

${ }^{2}$ Calculated from number of fruits with at least one locule showing moderate or severe IB.

${ }^{y}$ Calculated using the number of locules for each severity rating divided by the total number of locules with seeds for that treatment.

, ,**Nonsignificant or significant at $P=0.05$ or 0.01 , respectively.

Of the three cultivars tested, 'Sunny' was less susceptible to IB than 'Solar Set' and 'Cobia'. For these cultivars, a substantial number of MG fruit exhibited IB (5\% to $45 \%)$ as a result of one drop on opposite sides from $20 \mathrm{~cm}$; two drops on the same location from this height caused from $20 \%$ to $30 \%$ IB. As drop height increased, locules showing injury increased. BR tomatoes were more sensitive to impacts than MG, as previously reported (Halsey, 1955; Hatton and Reeder, 1963; Sargent et al., 1989a). 
Table 3. Effect of ripeness stage and drop height on incidence of IB of 'Cobia' tomatoes.

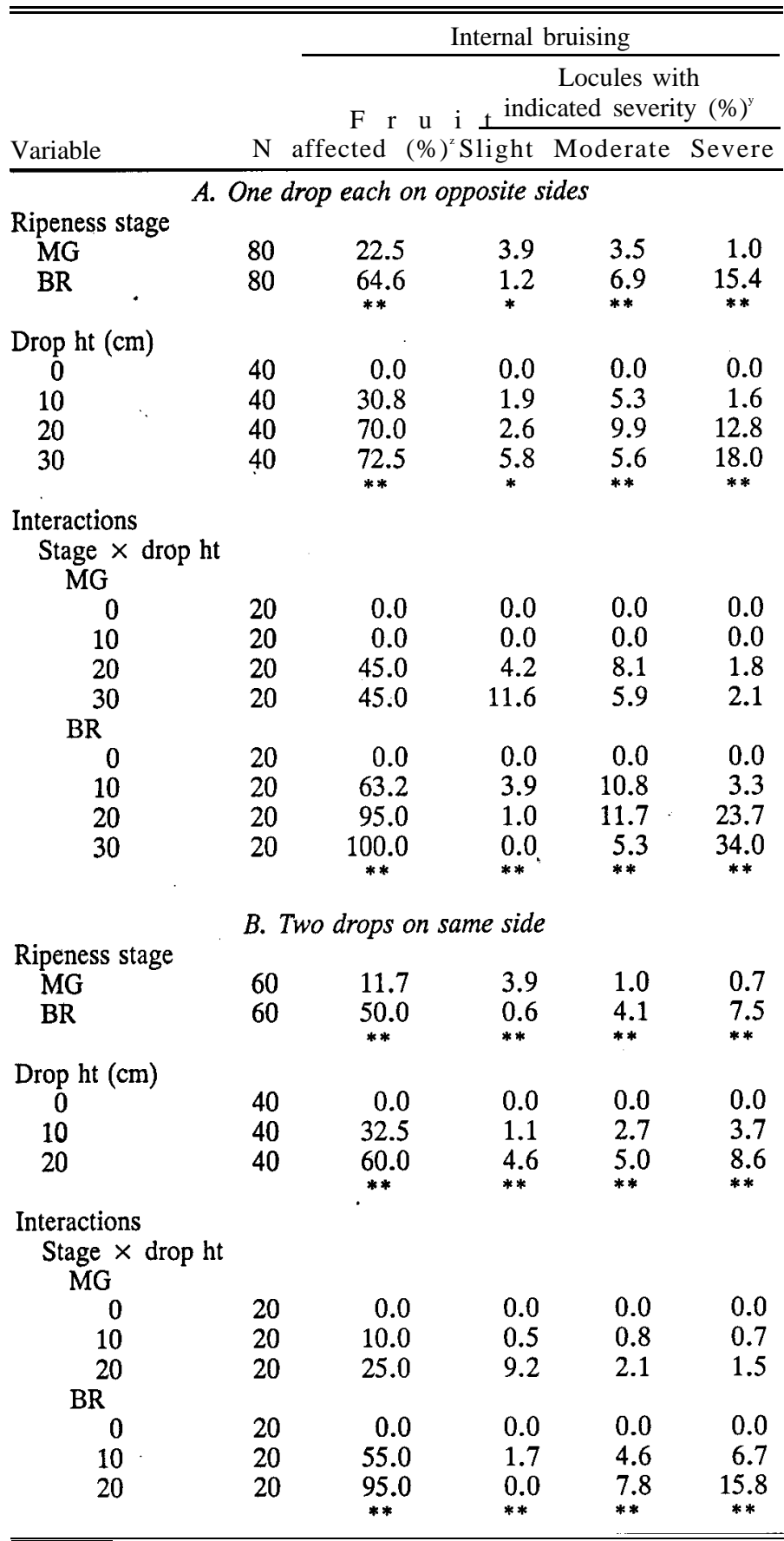

${ }^{2}$ Calculated from number of fruits with at least one locule showing moderate or severe IB.

${ }^{y}$ Calculated using the number of locules for each severity rating divided by the total number of locules with seeds for that treatment.

$*, * *$ Significant at $P=0.05$ or 0.01 , respectively.

Compression testing has shown that BR tomatoes are measurably softer than MG fruit when deformation is applied along the equatorial plane (Ahrens et al., 1987; Ahrens and Huber, 1990; Kader et al., 1978). In this study, single drops of BR tomatoes from $10 \mathrm{~cm}$ caused IB in $15 \%$ to $73 \%$ of fruit, while two drops on a single location from this height caused $50 \%$ to $67 \%$ (Tables 1, 2, 3). McColloch (1962) found that dropping MG 'Rutgers' tomatoes from $15 \mathrm{~cm}$ caused $50 \%$ of the fruits to have objectionable amounts of IB, and $67 \%$ of those dropped at turning/light-pink stages ( $20 \%$ to $40 \%$ red) had IB. Fruit firmness, as measured by resistance to deformation, also varies with cultivar and most likely influences cultivar susceptibility to IB. 'Sunny' was determined to be moderately firm among five cultivars of fresh-market tomatoes, when measured at the IB-sensitive BR stage (Ahrens and Huber, 1990).

While rating IB during this study, we observed that tomatoes had higher incidence and severities of IB when impacts occurred directly over the locule than when impacts occurred over the junction between the outer pericarp and the septum (radial wall). Impacts that occur directly over the locule appear to transmit maximum energy to the underlying gel, resulting in maximum expression of IB. Had it been possible to orient the fruit to ensure impact over a locule, the incidence and severity of IB attributable to the treatments likely would have increased. During commercial handling operations, tomatoes are typically transferred at least 15 times before packing. Although these transfer points often have impacts with sufficient force to induce $\mathrm{IB}$, the expression of IB is affected by fruit firmness and random impact location on the fruit.

Information from this study may be useful to tomato packinghouse managers and equipment manufacturers when analyzing or designing packing lines. Handling equipment and procedures should be designed to accommodate the most sensitive tomato cultivars and ripeness stages without causing injury. This goal can be accomplished by reducing the number of transfer points during handling and by lessening the impact levels at individual transfer points. The straightforward procedure described in this paper may also prove useful for evaluating tomato sensitivity to handling injury in breeding programs.

\section{Literature Cited}

Ahrens, M.J. and D.J. Huber, 1990. Physiology and firmness determination of ripening tomato fruit. Physiol. Plant. 78:8-14.

Ahrens, M. J., D.J. Huber, and J.W. Scott. 1987. Firmness and mealiness of selected Florida-grown tomato cultivars. Proc. Fla. State Hort. Soc. 100:39-41.

Ceponis, M.J. and J.E. Butterfield. 1979. Losses in fresh tomatoes at the retail and consumer levels in the greater New York area. J. Amer. Soc. Hort. Sci. 104(6):751-754.

Florida Tomato Committee. 1989. Annual report. Florida Tomato Committee, Orlando.

Halsey, L.H. 1955. Preliminary studies of bruising of "turning" and "pink" tomatoes caused by handling practices. Proc. Fla. State Hort. Soc. 68:240-243.

Hatton, T.T. and W.F. Reeder. 1963. Effect of field and packinghouse handling on bruising of Florida tomatoes. Proc. Fla. State Hort. Soc. 76:301-304.

Hicks, J. R., N.C. Hayslip, and R.K. Showalter. 1975. Consumer preferences in buying pink and red-ripe tomatoes. HortScience 10(1): 1112.

Holt, J.E. and D. Schoorl. 1982. Mechanics of failure in fruits and vegetables J. Text. Stud. 13:83-97.

Kader, A.A., L.L. Morris, and P. Chen. 1978. Evaluation of two objective methods and a subjective rating scale for measuring tomato fruit firmness. J. Amer. Soc. Hort. Sci. 103(1):70-73.

MacLeod, R. F., A.A. Kader, and L.L. Morris. 1976. Stimulation of ethylene and $\mathrm{CO}_{2}$ production of mature-green tomatoes by impact bruising. HortScience 11(6):604-606.

Maynard, D.N. 1990. Tomato cultivars for Florida. Proc. Fla. Tomato Inst. SS-VEC-001:95-99. Veg. Crops Dept., Univ. of Florida, Gainesville.

McColloch, L.P. 1962. Bruising injury of tomatoes. U.S. Dept. Agr. Mktg. Res. Rpt. 513. 
Mohsenin, N.N. 1970. Physical properties of plant and animal materials. Gordon and Breach Science Publishers, New York.

Sargent, S. A., J.K. Brecht, and J.J. Zoellner. 1989a. Assessment of mechanical damage in tomato packing lines. Amer. Soc. Agr. Eng. Paper no. 89-6060, St. Joseph, Mich.

Sargent, S.A., J.K. Brecht, J.J. Zoellner, K.V. Chau, L.A. Risse. 1989b. Reducing mechanical damage to tomatoes during handling and shipment. Amer. Soc. Agr. Eng. Paper no. 89-6616, St. Joseph, Mich.

SAS Institute, Inc. 1985. The SAS program for the personal computer.
SAS Institute, Inc., Cary, N.C.

Sober, S. S., H.R. Zapp, and G.K. Brown. 1989. Simulated packing line impacts for apple bruise prediction. Amer. Soc. Agr. Eng. Paper no. 89-6047, St. Joseph, Mich.

U.S. Department of Agriculture. 1976. United States standards for grades of fresh tomatoes. U.S. Dept. Agr., Agr. Mktg. Serv., Washington, D.C.

Wright, W.R. and B.A. Billeter. 1975. Marketing losses of selected fruits and vegetables at wholesale, retail and consumer levels in the Chicago area. U.S. Dept. Agr. Mktg. Res. Rpt. 1017. 